\title{
Irrigation management based on evapotranspiration accumulation of the melon crop: a Bayesian approach
}

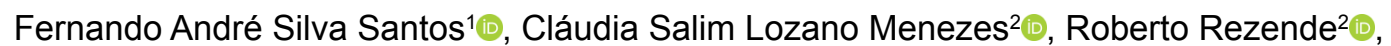

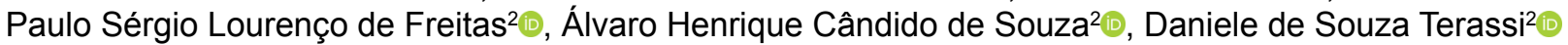

\footnotetext{
1 Universidade do Estado do Mato Grosso, Cáceres-MT, Brasil. E-mail: fernandoandre_agro2007@hotmail.com

2 Universidade Estadual de Maringá, Maringá-PR, Brasil. E-mail: claulozano93@gmail.com; rrezende@uem.br; pslfreitas@uem.br; alvarohcs@hotmail.com; daniele_terassi@hotmail.com
}

ABSTRACT: This study aimed to evaluate different accumulation values of the melon crop evapotranspiration (ETC) as a reference to start the irrigation. The study was conducted in a protected environment and the Bayesian methodology was used to analyze the data. Treatments consisted of four ETc accumulation values $(3,6,9$ and $15 \mathrm{~mm})$ for starting the irrigation, in addition to eight plots of control treatment, corresponding to the daily irrigation. Yield, total dry matter weight, leaf area, total chlorophyll, carotenoids and relative water content were all evaluated. Except for the relative water content, the a posteriori coefficient estimates of the regression models were all significant for the other variables, by fitting quadratic models to explain the ETc accumulation effect. In daily irrigation, total dry weight, leaf area, total chlorophyll and relative water content decreased while the carotenoids increased, compared to the accumulated irrigation. It is concluded that ETc accumulation changes production, growth and physiology of the melon and it is more beneficial than the daily irrigation. The Bayesian approach was adequate for explaining the relations between the water depths and the response variables of the melon.

Key words: Cucumis melo; micro irrigation; regression models; water consumption

\section{Manejo de irrigação baseado no acúmulo da evapotranspiração da cultura do melão: uma abordagem bayesiana}

RESUMO: Objetivou-se avaliar no presente trabalho diferentes valores de acúmulo da evapotranspiração da cultura do melão (ETc), como referência, para iniciar a irrigação. $O$ trabalho foi conduzido em ambiente protegido e fez-se o uso da metodologia bayesiana para análise dos dados. Os tratamentos constaram de quatro valores de acúmulo da ETc (3, 6, 9 e $15 \mathrm{~mm})$ para início da irrigação, além de oito parcelas de tratamento controle, correspondente a irrigação diária. Avaliou-se: produtividade, massa da matéria seca total, área foliar, clorofila total, carotenoides e conteúdo relativo de água. Excetuando-se o conteúdo relativo de água, observou-se que para as demais variáveis, as estimativas a posteriori dos coeficientes dos modelos de regressão foram significativas, ajustando-se modelos quadráticos para explicar o efeito do acúmulo de ETc. Na irrigação diária houve decréscimo de massa seca total, área foliar, clorofila total, conteúdo relativo de água e aumento de carotenoides comparado à irrigação acumulada. Conclui-se que o acúmulo de ETc altera produção, crescimento e fisiologia do meloeiro, sendo mais benéfico que a irrigação diária. Abordagem bayesiana foi adequada para explicar relações das lâminas e variáveis respostas do melão.

Palavras-chave: Cucumis melo; micro irrigação; modelos de regressão; consumo hídrico 


\section{Introduction}

Melon is one of the most important vegetables for Brazilian olericulture, with the irrigation standing as an important aspect in this crop, especially for protected environment conditions, in which there are still some obstacles in determining the opportune moment for carrying out the irrigation practice (Faria et al., 2015).

Irrigation management for most crops is based on fixed irrigation frequencies and variable water depths (Cavalcanti et al., 2015). However, this type of management does not always result in satisfactory production and quality, and it is of interest to evaluate irrigation from a fixed water depth based on the water consumption of the plant, as observed in other agricultural crops (Bertonha et al., 2004).

Linear and quadratic regression models are the most studied when evaluating the yield of irrigated crops, with the quadratic models often used for such since the water supply does not result in continuous increases in production. However, the said models may not be approved by the premises established in the frequentist analysis, making the use of other statistical approaches pertinent, with the Bayesian inference as an example (Rossi, 2011; Souza et al., 2016).

In the Bayesian approach, the combination of a probability distribution that allows inputting information a priori and the likelihood function derived from the data results in an a posteriori (posterior) distribution (Cotes et al., 2006). In this analysis, there is no obligation for homogeneity of the variance and adequacy of the residues to the normal distribution, representing an advantage in the data analysis made only by classical methodology. Despite being a robust statistical approach, its use is still restricted to experiments with vegetables (Teodoro et al., 2015) and is practically nonexistent in irrigation studies.

Given the above, the objective of this study was to evaluate different accumulated values of ETc as a basis for starting the irrigation of the muskmelon crop grown in a protected environment, using the Bayesian methodology for data analysis.

\section{Materials and Methods}

The study was conducted in a protected environment located in the Irrigation Technology Center (CTI) of the Maringá State University (UEM), situated in the municipality of Maringá-PR ( $23^{\circ} 25^{\prime} 57^{\prime \prime}$ S; 51 $57^{\prime} 08^{\prime \prime}$ W; $542 \mathrm{~m}$ ). The local climate is the Cfa subtropical type, as according to the Köppen classification.

The soil from the experimental area classifies as Dystroferric Red Nitisol (Rhodic Kandiudult) (Embrapa, 2018), with the following characteristics: $\mathrm{pH}\left(\right.$ in $\left.\mathrm{H}_{2} \mathrm{O}\right)=7.2$; Changeable $\mathrm{Al}$ $\left(\mathrm{cmol}_{\mathrm{c}} \mathrm{dm}^{-3}\right)=0.0 ; \mathrm{Ca}\left(\mathrm{cmol}_{\mathrm{c}} \mathrm{dm}^{-3}\right)=11.99 ; \mathrm{Mg}\left(\mathrm{cmol}_{\mathrm{c}} \mathrm{dm}^{-3}\right)=$ 2.50; $\mathrm{K}\left(\mathrm{cmol}_{\mathrm{c}} \mathrm{dm}^{-3}\right)=0.30 ; \mathrm{P}$ (Mehlich 1) $\left(\mathrm{mg} \mathrm{dm}^{-3}\right)=46.77$; organic matter $\left(\mathrm{g} \mathrm{dm}^{-3}\right)=15.55 ; \mathrm{V}(\%)=85.35 ; \mathrm{Zn}, \mathrm{Cu}, \mathrm{Fe}, \mathrm{Mn}, \mathrm{B}$ $\left(\mathrm{mg} \mathrm{dm}^{-3}\right)=20.34 ; 18.71 ; 68.87 ; 94.61 ; 0.16$, respectively; Clay $\left(\mathrm{g} \mathrm{kg}^{-1}\right)=756.8 ;$ Fine sand $\left(\mathrm{g} \mathrm{kg}^{-1}\right)=72.6$; Thick sand $\left(\mathrm{g} \mathrm{kg}^{-1}\right)=$ 50.0; Silt $\left(\mathrm{g} \mathrm{kg}^{-1}\right)=120.6$; soil specific gravity $\left(\mathrm{Mg} \mathrm{m}^{-3}\right)=1.01$.

After inverting the soil to a depth of $0.30 \mathrm{~m}$ the beds were built $(3 \times 0.5 \mathrm{~m})$, corresponding to the experimental plots. The soil received organic compost at the $0.5 \mathrm{~kg} \mathrm{~m}^{-2}$ dose per bed and the dosages of nitrogen $(\mathrm{N})$, phosphorus $(\mathrm{P})$ and potassium $(\mathrm{K})$ used in planting and top dressing fertilizations, calculated based on the soil analysis and the crop recommendation.

Treatments were arranged in a completely randomized design, in six replicates. They all consisted of four accumulation values of ETc that, when reached, triggered the irrigation start $(3,6,9$ and $15 \mathrm{~mm})$. In addition to the treatments, there were eight portions of a control treatment, corresponding to daily irrigation (no accumulation).

ETc was determined daily at 7:00 a.m. from the mean calculated by two constant water table lysimeters, placed in the center of the experimental area.

Transplanting occurred when the Sunrise hybrid seedlings had three to four definitive leaves, by using the spacing of $0.5 \mathrm{~m}$ between plants and $1.0 \mathrm{~m}$ between rows. The staking of the crop was done using plastic tear tape. Pollination was manually carried out and after the fruit picking, with thinning performed when necessary, by leaving one fruit per plant.

Irrigation was performed using a dripping micro-irrigation system. Each bed had a lateral line composed by a $16 \mathrm{~mm}$ diameter polyethylene tube, with 12 self-compensating drippers $0.25 \mathrm{~m}$ apart and a nominal flow of $8 \mathrm{Lh}^{-1}$. For applying the treatments in an individual and controlled manner, a sphere register was used at the beginning of each lateral line. Pressurization of the system was by a $0.5 \mathrm{hp}$ centrifugal pump operating at a pressure of 15 mca. Evaluation of the microirrigation system uniformity was through the Christiansen Coefficient (CUC), which resulted in a value of $97.55 \%$.

Shortly after the melon flowering period, two leaf discs were collected from the two central plants, on the fourth leaf below the apex of each plant, for extracting leaf pigments. With the readings, the contents of total chlorophyll (CLOR) and carotenoids (CAROT) (Lichtenthaler \& Wellburn, 1983), expressed in $\mu \mathrm{g} \mathrm{mL}^{-1}$, were calculated.

From the same leaves used to determine the pigments, four leaf discs were removed to determine the relative water content (RWC), in percentage (\%). This analysis used the weight of the fresh matter, turgid matter and dry matter of the discs, as according to the methodology present in Gong \& Chen (2012).

The harvesting point consisted of the abscission layer rupture of the fruit stalk and the skin yellow color. After each harvest, the fruits were individually weighed on a digital scale $(0.001 \mathrm{~g})$ in order to obtain the yield (YIEL) in $\mathrm{kg} \mathrm{m}^{-2}$.

After finishing the experiment, the plants were partitioned into roots, stems and leaves and subsequently dried in an oven with forced air circulation at $65^{\circ} \mathrm{C}$ until reaching constant mass in order to obtain the total dry matter weight (TDM) of the plant, expressed in $g_{\text {plant }}{ }^{-1}$. The leaf area (LA) was determined by using the digital image method and expressed in $\mathrm{m}^{2}$, as described by Lorenzoni et al. (2016). 
In the statistical analysis, the following two statistical models were evaluated: linear, with $y_{i}=\beta_{10}+\beta_{11} L_{i}+\varepsilon_{i,}$ and quadratic, with $y_{i}=\beta_{20}+\beta_{21} L_{i}+\beta_{22} L_{i}^{2}+\varepsilon_{i}$, where $y_{i}$ is the observed mean from each variable of the melon tree; $L_{i}$ is the accumulated water depth (in $\mathrm{mm}$ ); $\beta_{10}$ and $\beta_{11} ; \beta_{20}, \beta_{21}$ and $\beta_{22}$ are, respectively, regression coefficients from the linear and quadratic models; $\varepsilon_{i}$ are the random errors in a way that $\varepsilon_{i} \sim N\left(0, \sigma_{\varepsilon}^{2}\right)$.

Control data was considered to be normally distributed, that is, $\mathrm{y}_{0 \mathrm{i}} \sim \mathrm{N}\left(\mu_{0}, \sigma_{0}{ }^{2}\right)$, and a posteriori (posterior) contrast $\left(\Delta-y_{c}-\mu_{0}\right)$ was subsequently evaluated to check for possible differences between the control treatment, corresponding to daily irrigation and the treatments of accumulated water depth, with $\mathrm{y}_{\mathrm{c}}$ as the maximum value obtained with the quadratic regression model, if it was preferred instead the linear one. Within all procedures, non-informative a priori distributions were considered (Rossi, 2011).

Obtaining a posteriori marginal distributions for all parameters was by means of the BRugs package from the $R$ program (R Core Team, 2017). For such, 500,000 values were generated in an MCMC process (Monte Carlo Markov Chain), considering a sample disposal period of 10,000 initial values, making up the final sample containing 50,000 generated values, after being taken in size 10 thins. Convergence of the chains was verified through the coda package from the R program, as according to the criteria by Heidelberger \& Welch (1983).

Estimates of the a posteriori mean of the conditional marginal distribution of the parameters were used. The significance of these models was verified if the zero value did not belong to their respective $95 \%$ credibility interval $\left(P_{2.5 \%}-P_{97.5 \%}\right)$. For choosing the best regression model, the DIC (Deviance Information Criterion) criterion was used according to Spiegelhalter et al. (2002), in which the lower the DIC is, the better the fit also is, suggesting using this criterion for the difference module between the DIC values of two analyzed models ( $A$ and $B$ ), namely: $D=\left|D I C_{A}-D I C_{B}\right|$. Thus, $D$ $<5$ indicates that the difference is not significant, $5 \leq \mathrm{D} \leq 10$ that the difference is significant and $D>10$ that it is highly significant (Rossi, 2011).

\section{Results and Discussion}

The experimental cycle was of 89 days, period in which a total water depth of $294.5 \mathrm{~mm}$ was applied, with 56, 35, 25 and 16 irrigations performed for treatments related to the accumulated ETc of 3, 6, 9 and $15 \mathrm{~mm}$, respectively. The maximum daily value of ETc was $7.3 \mathrm{~mm}$, found on the 44th day after transplanting the crop.

In the regression models evaluation, the DIC criterion indicated that the quadratic model was the most appropriate to explain the relation between the response variables and the applied treatments, as displayed in Table 1.

By considering the difference module between the DIC values of two evaluated models, the differences were significant for all variables, with the exception of RWC, making the simplest model (linear) choice a feasible decision for expressing the relation between this variable and the accumulated water depths.

The synthesis of the posterior Bayesian estimates from the parameters (mean, standard deviation and 95\% credibility interval) of the regression models for the analyzed variables are displayed in the Table 2.

Table 1. DIC criterion values from the fitted regression models for yield, leaf area, total dry matter weight, total chlorophyll, total carotenoids and relative water content of the melon according to different levels of accumulated evapotranspiration depths as reference for the irrigation management.

\begin{tabular}{|c|c|c|c|c|c|c|}
\hline \multirow{2}{*}{ DIC } & \multirow{2}{*}{$\begin{array}{c}\text { YIEL } \\
\left(\mathrm{kg} \mathrm{m}^{-2}\right) \\
\end{array}$} & \multirow{2}{*}{$\begin{array}{c}\text { LA } \\
\left(m^{2}\right) \\
\end{array}$} & \multirow{2}{*}{$\begin{array}{c}\text { TDM } \\
\left(\text { g plant }^{-1}\right) \\
\end{array}$} & CLOR & CAROT & \multirow{2}{*}{$\begin{array}{c}\text { RWC } \\
(\%)\end{array}$} \\
\hline & & & & \multicolumn{2}{|c|}{$\left(\mu \mathrm{g} \mathrm{ml}^{-1}\right)$} & \\
\hline Linear DIC (L) & -10.82 & -17.67 & 157.1 & 36.37 & 76.98 & 118.8 \\
\hline Quadratic DIC (Q) & -17.91 & -23.25 & 149.9 & 31.23 & 71.87 & 120.7 \\
\hline
\end{tabular}

Table 2. A posteriori (posterior) Bayesian estimates of the parameters from fitted regression models and their respective credibility interval $\left(\mathrm{P}_{2.5 \%}-\mathrm{P}_{97.5 \%}\right)$ at the level of $95 \%$ for the response variables from melon plants in function of different accumulated evapotranspiration depths as a reference for irrigation management.

\begin{tabular}{|c|c|c|c|c|c|c|c|}
\hline Par. & Mean & SD & $\overline{\left(P_{2.5 \%}-P_{97.5 \%}\right)}$ & Par. & Mean & SD & $\left(P_{2.5 \%}-P_{97.5 \%}\right)$ \\
\hline \multicolumn{4}{|c|}{ YIEL $\left(\mathrm{kg} \mathrm{m}^{-2}\right)$} & \multicolumn{4}{|c|}{$\operatorname{CLOR}\left(\mu \mathrm{g} \mathrm{ml}^{-1}\right)$} \\
\hline$\beta_{0}$ & 0.8757 & 0.1451 & $(0.5825 ; 1.1580)^{*}$ & $\beta_{0}$ & 15.7400 & 1.3660 & $(12.9800 ; 18.3900)^{*}$ \\
\hline$\beta_{1}$ & 0.0997 & 0.0374 & $(0.0269 ; 0.1755)^{*}$ & $\beta_{1}$ & 0.7242 & 0.3524 & $(0.0389 ; 1.4370)^{*}$ \\
\hline$\beta_{2}$ & -0.0061 & 0.0019 & $(-0.0101 ;-0.0022)^{*}$ & $\beta_{2}$ & -0.0500 & 0.0187 & $(-0.0880 ;-0.0134)^{*}$ \\
\hline \multicolumn{4}{|c|}{$\mathrm{LA}\left(\mathrm{m}^{2}\right)$} & \multicolumn{4}{|c|}{ CAROT $\left(\mu \mathrm{g} \mathrm{m}^{-1}\right)$} \\
\hline$\beta_{0}$ & 0.5739 & 0.1180 & $(0.3355 ; 0.8033)^{*}$ & $\beta_{0}$ & 1.3740 & 0.4945 & $(0.3746 ; 2.3360)^{*}$ \\
\hline$\beta_{1}$ & 0.0833 & 0.0304 & $(0.0241 ; 0.1450)^{*}$ & $\beta_{1}$ & 0.3068 & 0.1276 & $(0.0587 ; 0.5649)^{*}$ \\
\hline$\beta_{2}$ & -0.0054 & 0.0016 & $(-0.0087 ;-0.0023)^{*}$ & $\beta_{2}$ & -0.0186 & 0.0067 & $(-0.0324 ;-0.0053)^{*}$ \\
\hline \multicolumn{4}{|c|}{ TDM (g plant ${ }^{-1}$ ) } & \multicolumn{4}{|c|}{ RWC (\%) } \\
\hline$\beta_{0}$ & 52.0100 & 9.6120 & $(32.5800 ; 70.6900)^{*}$ & $\beta_{0}$ & 81.1600 & 71.7500 & (71.7500; 90.0900)* \\
\hline$\beta_{1}$ & 6.3160 & 2.4810 & $(1.4910 ; 11.3300)^{*}$ & $\beta_{1}$ & -0.5841 & -2.8900 & $(-2.8900 ; 1.8450)^{\mathrm{ns}}$ \\
\hline$\beta_{2}$ & -0.4098 & 0.1321 & $(-0.6779 ;-0.1526)^{*}$ & $\beta_{2}$ & 0.0306 & -0.0994 & $(-0.0994 ; 0.1534)^{n s}$ \\
\hline
\end{tabular}

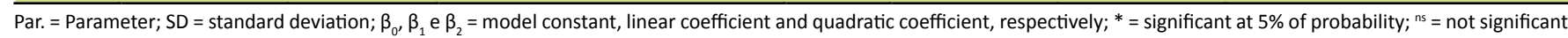


For the variables of growth (LA and TDM) and yield (YIEL), it was found that the coefficients of the models were significant at the level of $5 \%$ probability, given that the zero value is not contained in the credibility intervals $\left(P_{2.5 \%}-P_{97.5 \%}\right)$ for each variable. With the choice of the quadratic model, it was possible to estimate that the maximum yield of $1.28 \mathrm{~kg}$ $\mathrm{m}^{-2}$ is obtained with the application of an accumulated blade of approximately $8.04 \mathrm{~mm}$. For the LA and TDM variables, the maximum values $\left(0.89 \mathrm{~m}^{2}\right.$ and $\left.76.79 \mathrm{~g} \mathrm{plant}^{-1}\right)$ are obtained by applying water depths of 7.42 and $7.46 \mathrm{~mm}$, respectively.

Considering irrigation for melon, the relation between agronomic aspects and the amount of irrigation water in other studies are similar to those observed in this study, using the Bayesian procedure in the data analysis. For Gália-type melon, Ferraz et al. (2011) realized that the increase in water depths resulted in significant changes in growth variables such as the leaf area, with quadratic regression adjustment, and dry leaf and stem phytomasses, obtaining linear adjustments. Calvacanti et al. (2015) in the cultivation of the mandacarutype melon under irrigation, fitted linear models for the variables leaf area, leaf dry weight and stem dry matter.

Achieved results in studies involving irrigation in melon are mostly from fractional applications of crop evapotranspiration (\% of ETc), irrigating with fixed shifts and varying water depths, with few studies evaluating based irrigation. in fixed blades and variable irrigation shift on agronomic aspects, mainly those related to production and quality.

Higher values of accumulation between irrigations result in less frequency of water replacement, which results in water deficit, impairing melon production and growth. In treatments with a higher accumulation of evapotranspiration, less water availability reduced the leaf area, which may have increased stomatal resistance and reduced carbon assimilation. With less carbon assimilation, the accumulation of phytomass is also reduced, impairing production due to the lower supply of assimilates to the fruits, mainly from the stems and leaves, which constitute the main storage compartment in the melon (Queiroga et al., 2008).

As displayed in Table 2, for the variables CLOR and CAROT, the coefficients of the models were significant at the level of $5 \%$ probability, since the zero value is not contained in the credibility intervals $\left(P_{2.5 \%}-P_{97.5 \%}\right)$. With the adjustment of the quadratic models for CLOR and CAROT, it was possible to estimate that the maximum values for these variables are
18.48 and $2.65 \mathrm{mg} \mathrm{ml}^{-1}$ with the application of the accumulated water depths of 6.44 and $8,13 \mathrm{~mm}$, respectively. For the RWC, the value zero is not contained in the credibility interval of the linear and quadratic coefficients, indicating the absence of a significant difference at the level of $5 \%$ of probability, with no significant explanatory model for this variable.

As observed for the growth variables, the irrigation levels influenced the melon physiological variables. Despite the importance of measuring physiological changes due to irrigation, the evaluation of leaf pigments is not commonly presented in studies involving vegetables, with the presentation of results related to gas exchange and the photochemical efficiency of pigments such as chlorophyll being more common (Silva et al., 2015).

In comparison with other studies, it is noticed that the changes in leaf pigments are different from those observed for the present results. In the radish crop (Lacerda et al., 2017), the application of different water layers did not alter the total chlorophyll contents. For the cowpea culture, a reduction in the chlorophyll content was observed when the water depth decreased from the highest to the lowest (Bastos et al., 2012).

Similar to what was previously established for other variables in this study, physiological changes can be explained due to the occurrence of water deficit in treatments with greater accumulation of evapotranspiration, as according to Anjum et al. (2003), under water deficit the decrease in total chlorophyll is related to the inhibition of the precursor synthesis of this pigment. In the event of a reduction in chlorophylls, a photo inhibition process may also occur, which is also present in conditions of water deficit (Silva et al., 2014).

As explained by Taiz et al. (2017), carotenoids are accessory pigments that help absorb light and transfer energy to chlorophylls during the photosynthetic process, in addition to having a protective function. As chlorophyll and carotenoids are related, when there is a reduction in one, consequently there is a reduction in the contents of the other.

As chlorophyll is the main determinant pigment in capturing the light energy used in the photosynthesis process, it can be inferred that changes in irrigation management can influence the levels of this pigment (Bastos et al., 2012) and, in contrast, in growth and melon yield.

Table 3 shows the estimates of the Bayesian contrasts established between daily irrigation and accumulated water depths. There was a significance of the contrasts at the level

Table 3. A posteriori Bayesian estimates of the parameters for established contrasts and their respective credibility intervals $\left(P_{2.5 \%}-P_{97.5 \%}\right)$ at a level of $95 \%$ for yield, leaf area, total dry matter weight, total chlorophyll, total carotenoids and content relative water content of melon under daily irrigation and irrigation according to different accumulated evapotranspiration depths.

\begin{tabular}{|c|c|c|c|c|c|c|}
\hline Variable & Contrast & Mean & SD & Median & $\mathbf{P}_{2.5 \%}$ & $\mathbf{P}_{97.5 \%}$ \\
\hline YIEL $\left(\mathrm{kg} \mathrm{m}^{-2}\right)$ & $\mathrm{M} 1-\mathrm{M} 2$ & -0.0035 & 0.1297 & -0.0033 & -0.0315 & $0.0161^{n s}$ \\
\hline $\operatorname{LA}\left(\mathrm{m}^{2}\right)$ & $M 1-M 2$ & -0.0927 & 0.0813 & -0.0912 & -0.1645 & $-0.0245^{*}$ \\
\hline TDM (g plant $\left.{ }^{-1}\right)$ & $\mathrm{M} 1-\mathrm{M} 2$ & -8.4185 & 25.8335 & -8.1896 & -12.6667 & $-4.2725^{*}$ \\
\hline CLOR (mg mL-1) & $M 1-M 2$ & -0.3047 & 14.2325 & -0.2363 & -0.4534 & $-0.1178^{*}$ \\
\hline CAROT (mg mL-1) & $M 1-M 2$ & 0.2033 & 1.6665 & 0.2031 & 0.0924 & $0.2848^{*}$ \\
\hline RWC (\%) & $M 1-M 2$ & -2.7248 & 49.5539 & -2.7022 & -3.6095 & $-2.6109^{*}$ \\
\hline
\end{tabular}

$\mathrm{SD}=$ standard deviation; $\mathrm{M} 1$ = means obtained from the control (daily irrigation); $\mathrm{M} 2$ = maximum values found in the treatments with accumulated irrigation; ${ }^{*}=$ significant at $5 \%$ of probability; ${ }^{\mathrm{ns}}=$ not significant. 
Table 3. A posteriori Bayesian estimates of the parameters for established contrasts and their respective credibility intervals $\left(P_{2.5 \%}-P_{97.5 \%}\right)$ at a level of $95 \%$ for yield, leaf area, total dry matter weight, total chlorophyll, total carotenoids and content relative water content of melon under daily irrigation and irrigation according to different accumulated evapotranspiration depths.

\begin{tabular}{ccccccc}
\hline Variable & Contrast & Mean & SD & Median & P2.5\% & P97.5\% \\
\hline YIEL $\left(\mathrm{kg} \mathrm{m}^{-2}\right)$ & M1 - M2 & -0.0035 & 0.1297 & -0.0033 & -0.0315 & $0.0161^{\mathrm{ns}}$ \\
LA $\left(\mathrm{m}^{2}\right)$ & M1 - M2 & -0.0927 & 0.0813 & -0.0912 & -0.1645 & $-0.0245^{*}$ \\
TDM $\left(\mathrm{g} \mathrm{plant}^{-1}\right)$ & $\mathrm{M} 1-\mathrm{M} 2$ & -8.4185 & 25.8335 & -8.1896 & -12.6667 & $-4.2725^{*}$ \\
CLOR $\left(\mathrm{mg} \mathrm{mL}^{-1}\right)$ & $\mathrm{M} 1-\mathrm{M} 2$ & -0.3047 & 14.2325 & -0.2363 & -0.4534 & $-0.1178^{*}$ \\
CAROT $\left(\mathrm{mg} \mathrm{mL}^{-1}\right)$ & $\mathrm{M} 1-\mathrm{M} 2$ & 0.2033 & 1.6665 & 0.2031 & 0.0924 & $0.2848^{*}$ \\
RWC $(\%)$ & M1 - M2 & -2.7248 & 49.5539 & -2.7022 & -3.6095 & $-2.6109^{*}$ \\
\hline
\end{tabular}

$\mathrm{SD}=$ standard deviation; $\mathrm{M} 1$ = means obtained from the control (daily irrigation); $\mathrm{M} 2$ = maximum values found in the treatments with accumulated irrigation; ${ }^{*}=$ significant at $5 \%$ of probability; $^{\text {ns }}=$ not significant.

of $5 \%$ for five of the six variables analyzed. For production, there were no significant differences in the level tested in the comparison between treatments. For LA, TDM, CLOR and RWC, the zero value is outside the credibility intervals, indicating that the accumulated irrigation differed and exceeded the daily irrigation, given the negative values for the contrasts. The CAROT variable showed an opposite trend, with daily irrigation differing and surpassing accumulated irrigation.

In this study, to date, changes in melon variables have been justified by the occurrence of a deficit in treatments with a greater accumulation of evapotranspiration, however, the decreases observed for LA, TDM, CLOR and RWC in daily irrigation might be due to the possible excess of soil moisture.

It should be noted that naturally the melon is a crop originating in desert regions (Filgueira, 2013), and it has low water requirements, mainly in germination and emergence, that is, in the initial phase (Pires et al., 2013) and, in these terms, maintaining irrigation with uninterrupted supply can hinder its growth.

Water in excess can be reflected in the aerial part of plants, inducing chlorosis, wilting, a decrease in the photosynthetic capacity, water potential and nutrients concentration in the leaves, in addition to reduced growth (Visser et al., 2003). For the melon crop, many of the aforementioned changes can be associated with the measured variables, such as increased carotenoid content (likely yellowing), reduced chlorophyll content (probably less photosynthesis) and relative water content (indirectly representing water potential), decreasing the growth of the aerial part (total dry weight mass and leaf area).

Irrigation management for melon with a fixed depletion of water considering the losses due to the crop and the soil has promising application, mainly for soils whose texture does not allow good drainage. For other studies using the ETc accumulation between irrigations as a criterion for water application, positive results were found, maximizing fruit production and quality (Bertonha et al., 2004).

Moreover, the Bayesian approach to studies evaluating irrigation can be an interesting alternative in the data analysis, since with few experimental observations, it is possible obtaining more accurate information on when applying classical statistics (Souza et al., 2016) considering all the assumptions.

\section{Conclusions}

The production, growth and physiological aspects of melon conducted in a protected environment change when supplementary irrigation is used based on different values of accumulated evapotranspiration, with non-proportional increases as the irrigation interval increases.

For the current experimental conditions, the control treatment (daily irrigation) was less beneficial to melon compared to irrigation treatments based on different values of accumulation of evapotranspiration of the crop.

The Bayesian approach was adequate to explain relation between the accumulated water depths and the melon responses variable.

\section{Acknowledgements}

The present study was conducted with the support of the Coordination for the Improvement of Higher Education Personnel - Brazil (CAPES) - Financing Code 001.

\section{Literature Cited}

Anjum, F., Yaseen, M.; Rasul, E.; Wahid, A.; Anjum, S. Water stress in barley (Hordeum vulgare L.) II: effect on chemical composition and chlorophyll contents. Pakistan Journal of Agricultural Sciences, v. 40, n.2, p.45-49, 2003. https://pakjas.com.pk/ papers/536.pdf. 09 May. 2019.

Bastos, E. D.; Ramos, H. M. M.; Andrade Júnior, A. S. de.; Nascimento, F. N. do.; Cardoso, M. J. Parâmetros fisiológicos e produtividade de grãos verdes do feijão-caupi sob déficit hídrico. Water Resources and Irrigation Management, v. 1, n. 1, p.31-37, 2012. https:// ainfo.cnptia.embrapa.br/digital/bitstream/item/76294/1/ WRIM.pdf-P.31-37.pdf. 23 Apr. 2019.

Bertonha, A.; Gonçalves, A. C. A.; Freitas, P. S. L. de; Rezende, R. Resposta da laranjeira pêra em níveis de irrigação. Acta Scientiarum. Agronomy, v. 26, n. 2, p. 185-191, 2004. https://doi. org/10.4025/actasciagron.v26i2.1881.

Cavalcanti, N. M. da S.; Dutra, A. F.; Melo, A. S. de; Silva, F. G. da; Dutra, W. F.; Nunes Junior, E. da S. Aspectos agronômicos do meloeiro 'mandacaru' cultivado em ambiente protegido sob irrigação. Irriga, v. 20, n. 2, p. 261-272, 2015. http://doi.org/10.15809/ irriga.2015v20n2p261. 
Cotes, J. M.; Crossa, J.; Sanches, A.; Cornelius, P. A. A Bayesian approach for assessing the stability of genotypes. Crop Science, v. 46, n.6, p. $2654-2665$, 2006. https://doi.org/10.2135/ cropsci2006.04.0227.

Empresa Brasileira de Pesquisa Agropecuária. Sistema brasileiro de classificação de solos. 5.ed. Rio de Janeiro: Embrapa Solos, 2018. $356 \mathrm{p}$.

Faria, L.A.; Lima, E.M.C.; Siqueira, W.C.; Rezende, F.C.; Gomes, L.A.A. Qualidade de frutos de melão rendilhado cultivado em ambiente protegido sob diferentes lâminas de irrigação. Revista Brasileira de Agricultura Irrigada, v. 9, n.6, p.357-365, 2015. https://doi. org/10.7127/rbai.v9n600302.

Ferraz, R. L. de. S.; Melo, A. S. de; Ferreira, R. DE S.; Dutra, A. F.; Figueredo, L. F. de. Aspectos morfofisiológicos, rendimento e eficiência no uso da água do meloeiro "Gália" em ambiente protegido. Revista Ciência Agronômica, v. 42, n. 4, p. 957-964, 2011. https://doi.org/10.1590/S1806-66902011000400018.

Filgueira, F. A. R. Novo manual de olericultura. 3.ed. Viçosa: Editora UFV, 2013. $421 \mathrm{p}$.

Gong, H.; Chen, K. The regulatory role of silicon on water relations, photosynthetic gas exchange, and carboxylation activities of wheat leaves in field drought conditions. Acta Physiologiae Plantarum, v. 34, n.4, p. 1589-1594, 2012. https://doi. org/10.1007/s11738-012-0954-6.

Heidelberger, P.; Welch, P. Simulation run length control in the presence of an initial transient. Operations Research, v. 31, n. 6, p. 1109-144, 1983. https://doi.org/10.1287/opre.31.6.1109.

Lacerda, V. R.; Gonçalves, B. G.; Oliveira, F. G.; Sousa, Y. B. de; Castro, I. L. de. Características morfológicas e produtivas do rabanete sob diferentes lâminas de irrigação. Revista Brasileira de Agricultura Irrigada, v. 11, n. 1, p. 1127-1134, 2017. https://doi.org/10.7127/ RBAI.V11N100513.

Lichtenthaler, K.; Welburn, A. R. Determination of total carotenoids and chlorophylls $\mathrm{a}$ and $\mathrm{b}$ of leaf extracts in different solvents. Biochemical Society Transactions, v. 11, n.5, p. 591-592, 1983. https://doi.org/10.1042/bst0110591.

Lorenzoni, M. Z.; Rezende R.; Souza, A. H. C. de.; Seron, C. de C.; Hachmann, T. L.; Freitas, P. S. L. de. Response of bell pepper crop fertigated with nitrogen and potassium doses in protected environment. Agrotechnology, v. 5, n. 2, article 1000148, 2016. https://doi.org/10.4172/2168-9881.1000148.

Pires, M. M. M. L.; Santos, H. A.; Santos, D. F.; Vasconcelos, A. S.; Aragão, C. A. Produção do meloeiro submetido a diferentes manejos de água com o uso de manta de tecido não tecido. Horticultura Brasileira, v.31, n.2, p.304-310, 2013. https://doi. org/10.1590/s0102-05362013000200021.
Queiroga, R. C. F.; Puiatti, M.; Fontes, P. C. R.; Cecon, P. R. Partição de assimilados e índices fisiológicos de cultivares de melão do grupo cantalupensis influenciados por número e posição dos frutos na planta, em ambiente protegido. Revista Ceres, v.55, n.6, p.596-604, 2008. http://www.locus.ufv.br/bitstream/ handle/123456789/20556/artigo.pdf?sequence=1\&isAllowed=y. 23 Apr. 2019.

R Core Team. R: A language and environment for statistical computing. Vienna: The R Foundation for Statistical Computing, 2017. https://www.r-project.org. 05 Sep. 2017.

Rossi, R. M. Introdução aos métodos Bayesianos na análise de dados zootécnicos com uso do WinBUGS e R. Maringá: Eduem, 2011. $191 p$.

Silva, F. G. da; Dutra, W. F.; Dutra, A. F.; Oliveira, I. M. de; Filgueiras, L. M. B.; Melo, A. S. de. Trocas gasosas e fluorescência da clorofila em plantas de berinjela sob lâminas de irrigação. Revista Brasileira de Engenharia Agrícola e Ambiental, v. 19, n. 10, p. 946-952, 2015. https://doi.org/10.1590/1807-1929/agriambi. v19n10p946-952.

Silva, M. de A.; Santos, C. M. dos; Vitorino, H. dos S.; Rhein, A. F. de L. Pigmentos fotossintéticos e índice SPAD como descritores de intensidade do estresse por deficiência hídrica em canade-açúcar. Bioscience Journal, v. 30, n. 1, p. 173-181, 2014. http://www.seer.ufu.br/index.php/biosciencejournal/article/ view/15057/13696. 23 Apr. 2019.

Souza, O. M.; Martins, E. N.; Rossi, R. M.; Oliveira, C. A. L. de; Aguiar, S. C. de; Paula, E. J. H. DE; Geron, L. J. V.; Stivanin, T. E.; Ferreira, E. B. Ruminal $\mathrm{pH}$ and $\mathrm{N}-\mathrm{NH}_{3}$ behavior: a Bayesian approach. Semina: Ciências Agrárias, v. 37, n. 1, p. 311-320, 2016. https:// doi.org/10.5433/1679-0359.2016v37n1p311.

Spiegelhalter, D. J.; Best, N. G.; Carlin, B. P.; Van der inde, A. Bayesian measures of model complexity and fit (with discussion). Journal Royal of Statistical Society, v. 64, n. 4, p. 583-639, 2002. https:// doi.org/10.1111/1467-9868.02022.

Taiz, L.;Zeiger, E.; Moller, I. M.; Murphy, A. Fisiologia e desenvolvimento vegetal. 6.ed. Porto Alegre: Artmed, 2017. 888 p.

Teodoro, P. E.; Nascimento, M.; Torres, F. E.; Barroso, L. M. A.; Sagrilo, E. Perspectiva bayesiana na seleção de genótipos de feijão-caupi em ensaios de valor de cultivo e uso. Pesquisa Agropecuária Brasileira, v. 50, n. 10, p. 878-885, 2015. https://doi.org/10.1590/ S0100-204X2015001000003.

Visser, E. J. W.; Voesenek, L. A. C. J.; Vartapetian, B. B.; Jackson, M. B. Flooding and plant growth. Annals of Botany, v. 91, n. 2, p. $107-$ 109, 2003. https://doi.org/10.1093/aob/mcg014. 